OPEN ACCESS

UNIVERSITY OF THE

WEST of SCOTLAND

UWS Academic Portal

\title{
Gramsci, the United Front Comintern and Democratic Strategy
}

McNally, Mark

Published in:

Antonio Gramsci

DOI:

10.1057/9781137334183_2

Published: 12/08/2015

Document Version

Early version, also known as pre-print

Link to publication on the UWS Academic Portal

Citation for published version (APA):

McNally, M. (2015). Gramsci, the United Front Comintern and Democratic Strategy. In M. McNally (Ed.), Antonio Gramsci (pp. 11-33). (Critical Explorations in Contemporary Political Thought). Palgrave Macmillan.

https://doi.org/10.1057/9781137334183_2

\section{General rights}

Copyright and moral rights for the publications made accessible in the UWS Academic Portal are retained by the authors and/or other copyright owners and it is a condition of accessing publications that users recognise and abide by the legal requirements associated with these rights.

Take down policy

If you believe that this document breaches copyright please contact pure@uws.ac.uk providing details, and we will remove access to the work immediately and investigate your claim. 


\title{
1 \\ Gramsci, the United Front Comintern and Democratic Strategy
}

\author{
Mark McNally
}

\section{Introduction}

Antonio Gramsci is rightly regarded as one of the most important Western Marxists of the 20th century. This is largely due to the work of scholars like Perry Anderson, Noberto Bobbio, Stuart Hall and Ernesto Laclau and Chantal Mouffe. They returned to the history of 20th century Marxism in the 1960s, 1970s and 1980s to rediscover neglected intellectual currents, unsullied by the sins of Stalinism, which might still provide intellectual insights to radical socialist and democratic politics within and beyond the Marxist tradition. ${ }^{1}$ Gramsci's Italian heritage - and critical interest in the work of Croce and Machiavelli - was obviously important here. But of equal significance was the fact that immediately prior to his imprisonment in 1926 by Mussolini’s fascist state, Gramsci had penned two important letters to the Comintern that were critical of the early phase of Stalinism and its attack on party democracy. ${ }^{2}$ For some at least, these letters represented a kind of parting of the ways between East and West within Marxism, ${ }^{3}$ and Gramsci's Prison Notebooks emerge as one of the first great works of the Western Marxist tradition in its rejection of Eastern-style Marxism (and Stalinism in particular), and its development of a body of ideas tailored to the unique challenges of Western societies and their democratic culture.

One of the most important aspects of this East/West distinction has undoubtedly turned on the issue of political strategy. Gramsci's later writings in particular argue that a more democratic strategy would be required in the West than that which was employed in Russia in 1917. This strategy, while not rejecting a subsequent moment of revolutionary force, would be primarily characterized by an ideological battle to manufacture mass consent in civil society (a key dimension of the battle for 'hegemony'). From very different perspectives, Anderson and Laclau and Mouffe acknowledged the 'Eastern' sources of this Gramscian reconfiguration of political strategy for the West. Laclau and Mouffe, for example, identify the emergence of the concept of hegemony itself (and its 'logic of contingency') as partly a consequence of the necessity of Lenin and the Bolsheviks to develop a political strategy of building democratic alliances in response to the uneven development of capitalism in Russia and the need to defeat 
and transcend Tsarism. ${ }^{4}$ Anderson, by contrast, points to the 'Eastern' origins of Gramsci's concept of hegemony by relating its emergence to debates in Russian social democracy and the strategic coordinates of the United Front tactic devised by Comintern leaders in $1921-2 .^{5}$

In what follows in this chapter I pick up on Anderson's second point in particular and explore further the Eastern sources of Gramsci's theory of hegemony and more specifically the democratic strategy embedded in it. I do this by carrying out a closer analysis of the relationship of Gramsci's thought to the United Front Comintern than Anderson accomplished which, I maintain, is a relatively under-researched aspect of Gramsci's thought. ${ }^{6}$ Drawing on recent Comintern scholarship, the chapter considers the United Front as chronologically and spatially a broader and more uneven political phenomenon in the 1920s than Anderson or Laclau and Mouffe have recognized. They, in fact, tend to regard the United Front as a relatively short affair that was quickly and emphatically overtaken by extensive 'Bolshevization' and 'Stalinization' of Comintern parties in the aftermath of Lenin's death. ${ }^{7}$ I maintain, by contrast, that as a Comintern Representative in Moscow in 1922-3 at the height of the United Front and then as leader of the PCd'I (partito communista d'Italia) responsible for its implementation in Italy from 1924-6, Gramsci continued to engage in the politics of the United Front that had by no means been exhausted in this later period - at least not in Italy. In the above literature in general, Gramsci's Western Marxism is rightly defined against the Stalinist 'Third Period' of the Comintern (1928-33), but the focus on 'Bolshevization' and 'Stalinization' leads to a certain neglect of the Comintern's 'second period' (i.e. the period of stabilization and the United Front) and consequently obfuscates to some degree Gramsci's full intellectual debt to the 'Eastern' leaders of the Third International in his later writings. ${ }^{8}$ Retrieving this Comintern intervention in Western democratic politics therefore not only complicates any crude distinction between East/West in terms of Marxist theory in the early 1920s but, as I will argue in the conclusion, foregrounds a dimension of Gramsci's theory of hegemony - its democratic strategy that explains to some extent the continuing interest in his work today and invites further exploration in the context of its critical appropriation in Laclau and Mouffe's writings. ${ }^{9}$

\section{The United Front Comintern (1921-6)}

As is well known, Lenin and the leaders of the Russian Revolution established the Comintern (or Third International) in 1919 in a wave of revolutionary ardor that swept across Europe in the aftermath of the Bolshevik Revolution (1917). ${ }^{10}$ The Comintern, unlike its predecessor (the Second International), was established to be a truly 
revolutionary socialist movement committed to the violent overthrow of capitalism and the establishment of 'proletarian dictatorships' across the world on the Bolshevik model. The famous '21 Points' or 'Conditions for Admission' approved at its Second Congress (1920) thus 'declared war on the whole bourgeois world and on all scab social democratic parties' and demanded as its conditions of entry 'a complete break with reformism and "centrist" politics' and a commitment to 'regularly and methodically remove reformists and centrists from every responsible post in the Labor movement. ${ }^{11}$ This dogmatically sectarian political strategy was orientated by an overly optimistic Marxist-Leninist theory of crisis and a stagist account of economic history that displayed an illfounded confidence that 'moribund capitalism' was in terminal decline and a worldwide proletarian revolution was imminent and inevitable. ${ }^{12}$

By mid-1921, however, the certainty of capitalist collapse and proletarian revolution was rapidly ebbing. Revolutionary actions in Hungary (1919), Italy (1919-20) and Germany (1921) in these early years of the Comintern all ended in failure as the working masses declined to rally to the revolutionary call.- The Comintern was in the end forced to acknowledge that in the West at least the masses remained wedded to the pacifist and parliamentary traditions of social democracy. ${ }^{13}$ It was in this context that the United Front strategy gradually emerged in 1921-2 as a call to communist parties to transform themselves into mass-based popular movements. At the Third Congress, in July 1921, the Comintern thus adopted the slogan 'To the Masses.' ${ }^{14}$ This signaled that the era of blind confidence in revolutionary theory and the historical process delivering the people into their ranks had ended, and with it of course went any attempt to define communist strategy as one of pursuing power by an audacious strike on the state by a small, disciplined vanguard party - as some at least read the Bolshevik Revolution. Such 'leftist deviations' were now rarely tolerated and the United Front was in fact as much a campaign against intransigent elements within the ranks of the Comintern, who clung to them, as it was a colossal effort to win over the masses from social democracy and other popular forces. ${ }^{15}$

As is well known, the strategy was riven with contradictions and inconsistencies from the outset and achieved only partial successes. At times the United Front was presented as a direct appeal for joint action to reformist leaders ('the United Front from above'); on other occasions the Comintern dogmatically insisted that the appeal was only to be made to the reformist masses ('the United Front from below'); and in yet another configuration it was sometimes defined as incorporating both approaches simultaneously ('the United Front from 
above and below'). ${ }^{16}$ Despite these inconsistencies, the United Front had, nonetheless, a number of important and relatively consistent strategic coordinates aimed at winning the masses that Gramsci would inherit and elaborate on.

First, United Front tactics demanded a careful and realistic analysis by all parties of the balance of popular forces and, in particular, the mass capacities of communist parties vis-à-vis their opponents. In October 1922, Trotsky bluntly pointed out that revolutionary socialist movements 'rest directly only upon a fraction of the working class' and the task of communist parties was accordingly to 'win the confidence of the overwhelming majority of the working class. ${ }^{17}$ Crucially, it was this democratic deficit in the West that first placed mass tactics and strategy at center stage in Comintern circles.

Second, the United Front emphasized the necessity for tactical short-term alliances as a means to reach the social democratic and wider popular masses. At the core of this approach was accordingly a strategic maneuver to call on social democrats in particular to engage in 'joint actions' for the 'partial demands' of the workers. ${ }^{18}$ The aim of the Comintern was not, of course, organizational unity, but rather to mount a rearguard action that would disaggregate oppositional popular movements, detaching their base from the leadership by persuading the mass membership of the validity of communist ideology and tactics. ${ }^{19}$ The Bolsheviks' success was accordingly reframed as no longer due to an audacious 'frontal assault' in October 1917, but rather to their ability to employ tactics of flexibility, compromise and political maneuver over a longer period before the seizure of power. As Bukharin became a more important figure in the Comintern in 1923-6, and with the success of NEP (New Economic Policy) in Russia, the strategy of the United Front was supplemented with NEP themes and especially the alliance with the peasantry and sections of the rural and urban middle classes. ${ }^{20}$ As early as the Third Congress, Comintern leaders were thus alerting communists to the importance of these 'intermediary forces' in the West - the peasantry, the urban petit-bourgeoisie, technicians, white-collar workers and the intelligentsia - who were being 'drawn into the struggle between revolution and counter-revolution' and could 'assist the proletarian dictatorship in the period of transition from capitalism to Communism by helping with the problems of state and economic administration. ${ }^{21}$ By the Fourth Comintern Congress (1922), Bukharin was in fact claiming that the lessons of the worker-peasant alliance in Russia (the smycka) and its historic compromise with the peasantry under NEP were of 'general

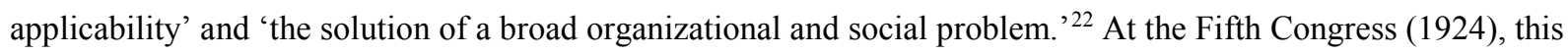
broadening of the popular reach of the United Front continued, as illustrated by the transformation of its slogan of 
'the Workers Government' to 'the Workers' and Peasants' Government', described tellingly as 'a deduction from the united front tactics. ${ }^{23}$

Third, the United Front revived Lenin's earlier theme of proletarian 'leadership' in a bloc of anti-Tsarist forces, ${ }^{24}$ applying it now to the West, and the need for a new kind of leadership in an alliance of anti-capitalist forces. The Party's task was therefore 'to lead the immediate struggles of the working masses for their most vital interests,' taking the initiative in the fight for better wages, working and living conditions, and demonstrating that the communists were the most vital and committed force to pursue these. ${ }^{25}$ It was assumed, in fact, that in these joint actions a point would be reached when the reformist leadership would refuse to take the battle to open confrontation with capitalism. In these circumstances communists would expose their lack of resolve to their mass base who - it was thought - would then swarm into the ranks of the unwavering communists. ${ }^{26}$ This emphasis on leadership was also applied beyond the proletariat to the peasantry and the rural and urban lower middle classes. At the Fourth Congress (1922) - which Gramsci attended as a PCd'I Representative - Zinoviev thus insisted on the need for workers 'to lead all oppressed layers in the struggle against the bourgeoisie.' 27

Finally, since United Front tactics involved making alliances with non-revolutionary forces, great weight was placed on the need for communist parties to preserve their revolutionary principles and maintain their 'autonomy' in any bloc formed. ${ }^{28}$ Indeed, it was this concern that initially instigated the campaign of Bolshevization in the aftermath of the abortive German Revolution of 1923 - the so-called 'German October' - in which the KPD (German Communist Party) was accused of placing too much faith in the degenerate leaders of 'social democracy.' 29 Bolshevization, with its emphasis on greater centralization and ideological homogeneity, would eventually provide the pretense for the Russification and Stalinization of the Comintern in the mid- to late 1920s. But it is important to recognize that at the outset, in 1924-6, this was an uneven process that largely depended on whether the Comintern saw the danger from the 'Right' (who supposedly had flirted with more substantial alliances with the reformists), or the radical 'Left' (who sought to return to the surer ideological world of the vanguardism and political isolationism of the 21 Points). ${ }^{30}$ Crucially, in the Italian context, it was the Left, led by Amadeo Bordiga, which presented the greater danger, and it was the task of Antonio Gramsci as PCd'I leader to confront this political challenge up to 1926. Indeed, this political challenge not only shaped Gramsci's immediate pre-prison writings, but also his project in the Prison Notebooks where the United Front is critically appropriated and Gramsci thinks through how 
revolutionary socialism can elaborate a democratic strategy to achieve hegemony in the complex political, economic and ideological arenas of modern Western democracies.

\section{The United Front and Gramsci's 'Relations of Force'}

The United Front, as we have seen, involved a turn toward careful analysis of popular politics, not only the popular solidity of communist parties, but also social democratic parties and unions and a broad array of 'intermediate forces.' This aspect of United Front tactics clearly informed Gramsci's development of a mode of social analysis in the Prison Notebooks centered on his concept of 'relations of force.' In his pre-prison writings Gramsci had indeed already begun to analyze the 'relations of force' in Italy guided by United Front tactics. In 1926 he wrote:

For all the capitalist countries, a fundamental problem is posed - the problem of the transition from the united front tactic, understood in a general sense, to a specific tactic which confronts the concrete problems of national life and operates on the basis of the popular forces as they are historically determined. ${ }^{31}$

This problematic would provide a rich seam for a broader and deeper exploration of the plurality and historical configuration of popular political forces in the Italian political arena in the Prison Notebooks. But in his pre-prison writings Gramsci tended to theorize these as a consequence of Italy's backward and uneven economic development. In 'peripheral states' he thus maintained 'a broad stratum of intermediate classes stretches between the proletariat and capitalism: classes which seek to carry on, and to a certain sense succeed in carrying on, policies of their own, with ideologies which often influence broad strata of the proletariat, but which particularly affect the peasant masses. ${ }^{32}$ The analysis moreover was clearly aimed at democratic results and historically grounded. 'Particular attention,' Gramsci thus maintained, 'must be accorded to the groups and parties that have a mass base. . . among the agricultural population of the South and islands. ${ }^{33}$

This mode of analysis was taken up again in the Prison Notebooks in a much more diverse and generalized manner in some of Gramsci's most important notes on 'Relations between Structure and Superstructures' and the theorization of hegemony which it underpinned. In Notebook 4 in particular Gramsci extended this analysis of the 'relations of forces' under three categories: the 'relation of social forces' (classes); 'the political "relation of forces"' and the 'relation of military forces.' The second set of relations is crucial for Gramsci since it is at this level - 'the most patently "political" phase' - that one leading group's ideology 'tends to prevail, to dominate, to spread across the entire field, bringing about, in addition to economic and political unity, intellectual and moral unity, not on a 
corporate but on a universal level: the hegemony of a fundamental social group over the subordinate groups. ${ }^{34}$ While the marks of the Comintern's call to evaluate and study carefully the balance of popular forces as a crucial preparation for revolutionary strategy are clearly visible here, there is no doubt too that Gramsci broadened its parameters extensively and in the process extended his conception of politics to give ideological struggle a much more central status. Leadership, or hegemony in Gramsci's terms, now required careful analysis of all historically grounded political and ideological elements with the aim of molding a form of 'intellectual and moral unity' around 'a fundamental social group.' This was above all the task of the leading group's political party and here again the coordinates of United Front strategy were important for Gramsci.

\section{The United Front and Gramsci's 'Modern Prince'}

As we have seen, by 1924, after some initial resistance, Gramsci had in fact come to share the United Front Comintern's view that a major obstacle to mass politics in its ranks was the excessively 'vanguardist' Party organizational principles pursued by Comintern 'Lefts.' This was particularly important in the Italian context where one of its leading lights, Amadeo Bordiga, as leader of the PCd'I from 1920-3 had organized the Italian Party as a closed, centralized and highly disciplined revolutionary movement in line with the 21 Points. ${ }^{35}$ In the debates on the United Front within the Italian Party, Bordiga defended vigorously his conception of the Party as a small revolutionary elite united by its iron discipline and unbending commitment to revolutionary Marxist theory. The United Front's 'politicking,' he maintained, would bring about the degeneration of the Party into 'opportunistic labourism' as untrustworthy elements entered its ranks and corrupted its revolutionary principles. ${ }^{36}$ This conception of the Party was roundly criticized by the United Front Comintern, including the Bukharinist Comintern Representative to Italy, Jules Humbert-Droz. He left the PCd'I in no doubt during his period in Italy in 1924 that its rigid, hierarchical Party structure, developed under the leadership of Bordiga - and initially preserved under Gramsci - was hopelessly inadequate for the United Front's mass political action. In a letter to Zinoviev in April 1924, Humbert-Droz roundly condemned the PCd'I Executive for failing to implement United Front tactics. He complained in particular of lack of mass initiative, reporting that 'The electoral period was not at all used as it should have been to gain public support for the Party' as the PCd'I was 'too absorbed in its own internal disputes to return to the arena of public life.' To remedy this situation, Humbert-Droz demanded 'more frequent meetings of the party executive in which questions of general politics and the tactics of the party were on the agenda. ${ }^{, 37}$ It is notable 
that by September of the same year, as Gramsci's leadership of the PCd'I consolidated, he was reporting significant improvements in the application of United Front tactics:

The work among the peasantry has already begun with zeal and is producing notable results.... We must not forget that just four months ago the Party was completely absorbed in its own internal struggles and completely illegal. . . . I have managed to convince myself of the constant effort of the Secretariat to stimulate initiative in the battle against sectarianism and to lead the Party on to our terrain. ${ }^{38}$

The traces of these strategic coordinates of the United Front tactics, endorsed by Bukharin and Humbert-Droz in particular in this period, are clearly visible in the Prison Notebooks, and especially in Gramsci's account of the revolutionary party ('the Modern Prince').

In the Prison Notebooks, Gramsci in fact returns to Bordiga's elitist and 'pseudo-aristocratic' approach to party organization, condemning it as yet another contribution to 'the apoliticism and passivity of the great popular masses' that had long plagued progressive politics in Italy. ${ }^{39}$ "“Vanguards" without armies to back them up' are accordingly contrasted unfavorably by Gramsci to a political strategy in which the party's intellectuals 'are conscious of being linked organically to a national-popular mass ... and stimulate the formation of homogenous, compact social blocs, which will give birth to their own intellectuals. ${ }^{40}$ For Gramsci, then, if parties are to develop the capacity to win and lead the masses they must develop an organizational structure characterized by multiple strata of intellectuals of different grades and specializations with the possibility of upward mobility. Crucially, this is what would ensure their capacity to forge organic links with the masses in civil society. ${ }^{41}$

It was of course the absence of this 'organic' link with the urban and rural masses manifested in the failed revolutionary surges of the early 1920s and in Bordiga's PCd'I which had inspired the United Front strategy in the first place. Taking up this problem of a democratic deficit, Gramsci gives special attention to the party's development of a mass ideological strategy. In particular, he attacks vociferously ideological orientations based on narrow class sectarianism ('economic-corporatism') typical of the Left which he identifies as characteristic of primitive or declining political formations. This approach is toxic to any possibility of victory among the masses since it involves a form of dogmatic guardianship of class and revolutionary principles and values - induced by the experience of social democracy's descent into class collaboration - which ultimately isolates the Party from the masses organized in popular political movements (including social democratic parties and unions) and wider civil 
society associations. ${ }^{42}$ In fact, from this perspective, adversarial leaders and the masses are treated en bloc as ideological enemies who must be defeated, not assimilated, since their integration necessarily leads to the corruption of communist principles.

In answer to this vanguardist account of party ideology modeled on the 21 Points, Gramsci insists that 'the proletariat, in order to become capable as a class of governing, must strip itself of every residue of corporatism, every syndicalist prejudice and incrustation. ${ }^{43}$ Ideological struggle, moreover, should not be reduced to pocket-book recitals of Marxist-Leninist revolutionary principles or rigid sectarian accounts of laws of economic history that paint all opponents as petit-bourgeois and reformist 'dupes. ${ }^{34}$ The Party must rather adopt a creative and constructive approach to ideological struggle that involves finding the right language and slogans that will mobilize and create organic links with a concrete historically determined mass. But, in line with the United Front's emphasis on fundamental principles and autonomy of action, Gramsci is nonetheless careful to insist that there are clear limits to this constructive act, since sacrifices and compromise in ideological terms 'cannot touch the essential. ${ }^{2}$

In the Prison Notebooks Gramsci extends the boundaries of the strategic coordinates of the United Front in relation to party ideology, suggesting in fact that its ideology must develop reciprocally and dialectically with the national-popular elements it seeks to win over and become embedded in the consciousness and praxis of the masses. For Gramsci, this process of 'nationalizing' and democratizing the party's ideology is a process which can be characterized as transforming the 'common sense' of the masses (its largely incoherent and spontaneous 'traditional conception of the world') into a form of 'good sense' in which the 'philosophy of praxis' (i.e. Marxism) is 'diffused in such a way as to convert itself into an active norm of conduct' 46 and in fact becomes 'rooted in the popular consciousness with the same solidity and imperative quality as traditional beliefs. ${ }^{, 47}$ Leaving aside for the moment the possibility of contradiction and conflicts of values in this new ideological synthesis which I return to below, its strategic democratic element is nonetheless clear as what Gramsci is committing the Party to in this move to mobilize the masses is an abandonment of revolutionary purism and a commitment to articulate Marxism to 'extraneous' national-popular ideological elements that are historically embedded in the political terrain it is attempting to hegemonize.

It is also crucial for Gramsci that the Party relates this attempt to achieve 'intellectual and moral reform' to concrete political action and especially 'a programme of economic reform.' Indeed, he argues 'the programme of 
economic reform is the concrete way in which every intellectual and moral reform expresses itself. ${ }^{48}$ For Gramsci this political manifestation of the ideological struggle takes two forms that recall United Front tactics. First, it involves engaged participation and leadership in political campaigns and direct action launched in cooperation with the urban and rural masses for immediate demands. Second, it requires the incorporation of these demands into a coherent party programme for government. In his intervention at the PCd'I's Como Conference on his return from Comintern duties, Gramsci thus defended openly for the first time the United Front slogan of the 'Workers' and Peasants' Government' launched at the Fifth Congress in precisely these terms arguing that they were crucial to win over in particular the rural masses in Italy's Mezzogiorno:

it is necessary to win over these masses, and this can be done only by participating in the struggles which they launch for partial victories and partial demands. The 'workers' and peasants' government' slogan must serve to bring together and synthesize the content of these partial struggles, in a programme which can be understood even by the most backward masses. ${ }^{49}$

This was a theme which Gramsci returned to in the Prison Notebooks in his important consideration of the failure of the radical bourgeois party in the Italian Risorgimento (the Action Party) to take leadership of the national reawakening from the more 'reactionary' yet tactically astute Moderate Party and thereby give the Italian State a sounder political base among the masses. For the Action Party 'to have succeeded at the very least in stamping the movement of the Risorgimento with a more markedly popular and democratic character,' Gramsci therefore argues, "it would have had to counterpoise to the "empirical" activity of the Moderates ... an organic programme of government which would reflect the essential demands of the popular masses, and in the first place of the peasantry. ${ }^{50}$ In an obvious reference to the Comintern's difficulties in pursuing a similar strategy in the 1920 s in the face of Leftist charges of class compromise and a descent into reformism, Gramsci identifies this democratic strategy as a form of positive 'Jacobinism' to be contrasted to a negative version of the same concept. The 'constructive' approach of 'having made the demands of the popular masses one's own' is thus to be privileged over a regressive 'destructive' Jacobinism that 'derived from hatred of rivals and enemies ... the sectarian element of the clique, of the small group, of unrestrained individualism, more than the national political element. ${ }^{51}$ 


\section{The United Front and Gramsci's Democratic strategy}

While the Comintern's conception of the Party leading a 'United Front' of popular forces is one of the key points of departure for Gramsci's theory of hegemony, it is the manner in which Gramsci marries his interests in democratic politics (winning over the masses) to ideological strategy that distinguishes his approach and gives it continuing resonance today. In fact, this leads to an extraordinary radicalization and extension of the conceptions of 'leadership' and 'alliance-building' in Gramsci's later writings that provides us with a new vision of democratic politics aimed at constructing and maintaining organic bonds with the working masses and a range of other historically constituted popular forces in civil society. Indeed, for Gramsci only organic bonds of this nature provide solid and enduring 'state' power, understood in the Gramscian sense, as 'State $=$ political society + civil society'. ${ }^{52}$ An examination of the democratic strategy incorporated into Gramsci's account of hegemony not only reveals its debt to the Comintern's United Front but, again, its elaboration into a more strategically sophisticated, democratic and pluralistic account of politics.

In the Prison Notebooks Gramsci in fact identifies the United Front with Lenin's abandonment of the failed leftist strategy of 'war of manoeuvre' (frontal assault) for a new strategy of a 'war of position':

It seems to me that Ilitch understood that a change was necessary from the war of manoeuvre applied victoriously in the East in 1917, to a war of position which was the only form possible in the West.... This is what the formula of the 'United Front' seems to me to mean. ... .

In a move that was typical of Comintern discourse in the wake of Lenin's death, Gramsci in fact identifies 'the war of position' and hegemony itself as 'Leninist' innovations. ${ }^{54}$ More importantly, he clearly links the necessity to conduct politics in this manner as a consequence of the age of democratic states in the West:

The massive structures of the modern democracies, both as State organisations, and as complexes of associations in civil society, constitute for the art of politics as it were the 'trenches' and the permanent fortifications of the front in the war of position: they render merely 'partial' the element of movement which before used to be 'the whole' of war, etc. ${ }^{55}$

The echoes of the United Front strategy to abandon frontal assaults and embark on a great ideological campaign to win over the masses in the West are evident. However, for Gramsci parties that aim to acquire state power in the modern democracies must first adopt a strategy to establish 'trenches' and 'fortifications' for that power. This was a 
radical step beyond the United Front as it implied more robust and enduring relations with other subaltern classes and associations that would form 'a complex of associations in civil society.'

Gramsci also takes up the United Front conception of leadership in his theory of hegemony, marrying it to a more sophisticated account of the relations of force and a broader and deeper conception of a democratic alliance. He thus begins with the United Front necessity for autonomy of action, insisting that leadership and hegemony develop dialectically and the point of departure must include a determination of the Party not to resign itself to 'auxiliary' status. It was for this reason he resolutely rejected Pierro Sraffa's call in 1924 for the PCd'I to simply support the 'democratic opposition' to fascism as a move that would consign the communists to subalternity and ultimately 'liquidation. ${ }^{56}$ In the Prison Notebooks he insists that hegemony requires a party to take the initiative in the event of political crises and dislocations in the oppositional bloc; to get to the head of them and turn them to their ideological advantage by extending their allies, popular influence and building consent for their ideological goals. In this endeavor, studies of the relations of force are consequently not 'ends in themselves' but always aimed at

the permanently organized force that can be pushed forward when the situation is propitious (collapse of the enemy, crises, etc.). The essential task is to work systematically to form, develop, and enlarge this force and to make it ever more homogenous, compact, and self-aware. . . ${ }^{57}$

For Gramsci this 'forward movement' was a political and ideological struggle that must be strategically calibrated for success. It could not therefore take the form of a dogmatic adherence to principle on the political issues of the day, but rather must be approached as a series of 'points of departure, ${ }^{58}$ aimed at expanding and consolidating one's own forces through compromise in the initial stages, while simultaneously forging a deeper consent for the ideological goals of the movement in the long term.

Part and parcel of every hegemonic strategy of this nature is thus the 'molecular' building of a series of democratic relations with allies that also sets out in the process to disintegrate and disaggregate opposition parties and movements and their alliance of forces. This of course was orientated by the United Front's call for 'a rearguard action' against primarily social democracy that distinguishes the proletarian and peasant masses from both their reformist and petit-bourgeois leadership, aiming to win them over to Comintern parties. In a letter to Togliatti in 
1923 in which he sought to convince his comrade of the impotency of polemical 'frontal assaults' on reformists and the strategic efficacy of the United Front, Gramsci thus argued:

Three years' experience has taught us, not just in Italy, how deeply-rooted social-democratic traditions are, and how difficult it is to destroy the residues of the past through ideological polemics. An immense and at the same time painstaking political action is necessary, that can break down this tradition day by day, by breaking down the organism which embodies it.

In order to achieve this Gramsci maintained the party 'must not continue to make en bloc counterpositions, but must distinguish between leaders and mass base' and 'find all the elements of disagreement between the leaders and the mass base and deepen these, enlarge them, generalize them politically. ${ }^{59}$

In a clear reformulation of the United Front, Gramsci already was arguing in 1926 that as far as direct political opponents such as social democrats and popular peasant parties are concerned, the manner in which the process of disintegration-reintegration (the 'war of position') operates hinges on the ability of the Party's organic intellectuals to win over not the central leadership of these opposition movements (an unrealistic adventure), or in the first instance the mass base, but rather their 'intermediate stratum' which 'maintains the link between the leading group at the top, and the mass of members and those influenced by the party. ${ }^{90}$ This approach was again to be generalized in the Prison Notebooks, ${ }^{61}$ but it first emerged as a reflection on the relative success of the PCd'I's application of United Front tactics in $1926 .{ }^{62}$ It was not sufficient, however, to win over middle-ranking strata of intellectuals in opposing - yet socially - contiguous parties since hegemony assumed a much broader leadership across political and civil society. Thus Gramsci maintained that hegemonic parties must also aim to assimilate 'traditional intellectuals,' that is to say, intellectuals who have no 'organic' relationship to any social class or party and who 'put themselves forward as autonomous and independent of the dominant social group.' While this autonomy for Gramsci is ultimately spurious, he is acutely aware that their abandonment of the old political order for compliance (or passive consent) with a new order is a vital step in gaining the confidence and support of the wider masses. According to Gramsci then, 'One of the most important characteristics of any group that is developing towards dominance is its struggle to assimilate and to conquer "ideologically" the traditional intellectuals. ${ }^{63}$ This is the task of the political party which 'is responsible for welding together the organic intellectuals of a given group the dominant one - and the traditional intellectuals. ${ }^{64}$ At times he suggests in the Notebooks that some categories of 
traditional intellectuals were initially formed as the organic intellectuals of classes that had since been superseded (clerics were, for example, the organic intellectuals of the feudal order), ${ }^{65}$ but for Gramsci what was strategically important was to forge relationships with and ideologically influence those traditional intellectuals who retained a strong 'national-popular' character. This meant above all those intellectuals who held influence over the rural workers and petit-bourgeoisie since they made up the large majority of the population in many European states, including Italy, at the time.

However, a democratic strategy of this character which placed the Party at the hub of a mass 'complex of associations in civil society' mediated through networks of 'intellectuals' inevitably presented Gramsci with new strategic challenges that the Comintern's narrower approach had not envisaged. Foremost among these was how to maintain unity in this more diverse and pluralized political formation, and, above all, to avoid internecine conflict which would of course open up the possibility of disintegrative processes that could be exploited by opposition forces. In an effort to resolve this tension in his thought and resolve this strategic necessity, Gramsci drew heavily on the language of balance and equilibrium, using them to develop his account of hegemony and ideological struggle. ${ }^{66}$ In the Prison Notebooks Gramsci in fact conceives of the unity achieved in such a bloc of forces as a kind of equilibrium:

the development and expansion of the particular group are conceived of, and presented, as being the motor force of a universal expansion, of a development of all the 'national' energies. In other words, the dominant group is coordinated concretely with the general interests of the subordinate groups, and the life of the State is conceived of as a continuous process of formation and superseding of unstable equilibria. ${ }^{67}$

Indeed, leadership now required that the Party carried out a 'balancing function' in which it not only 'balances the various interests struggling against the predominant (but not absolutely exclusivist) interest,' but also takes responsibility for "holding the balance between the various interests in "civil society." This 'hegemonic function" ${ }^{68}$ went beyond a simple compromise of interests since for Gramsci it required a form of unity at the level of ideology to transform and assimilate new elements to the bloc and to thwart disintegrative tendencies.

It was in this dual balancing function of checking disintegrative tendencies and staving off competition where Gramsci's account of hegemony and democratic strategy is most innovative, moving well beyond the Comintern's United Front. For Gramsci now offers in the Prison Notebooks two tantalizing suggestions of how 
destabilization at the mass base are to be checked and the danger of the siphoning of support avoided. Education and criticism of disintegrative elements in the bloc were the key 'checking' mechanisms that were vital for the establishment of a dynamic equilibrium for Gramsci. The task then of 'the first representatives of the new historical phase' is to perform a 'criticism' of these elements that 'results in a process of differentiation and of change in the relative weight that the adherents of the old ideologies used to possess.' This was not simply a matter of 'checking' elements that had previously been allied to capitalism, but bonding them to the center by persuading them of the legitimacy of the core ideology in the bloc. This would lead to a situation in which 'what was once considered secondary and subordinate, or even incidental, comes to be seen as primary and becomes the nucleus of a new ideological and theoretical complex. ${ }^{69}$ For the 'historical act' of revolution, Gramsci argues, 'can only be performed by a "collective man" which presupposes "the attainment of a "cultural-social" unity through which a multiplicity of dispersed wills, with heterogeneous aims, are welded together with a single aim, on the basis of an equal and common conception of the world, both general and particular. ${ }^{, 70}$

\section{Conclusion}

In this chapter I have argued that the Comintern's United Front provided Gramsci with the rudimentary elements of an important dimension of his theory of hegemony in its first attempt to develop a democratic strategy for the West and especially the defeat of social democracy. While this does not amount to a rejection of Gramsci's status as a Western Marxist, it does require that we acknowledge at least that a vital aspect of his theory of hegemony had important Eastern roots in that it was predominantly the leaders of the Russian Revolution - Lenin, Bukharin, Trotsky and Zinoviev - who played the central role in devising this strategy. The Comintern's turn away from democratic politics in 1926-8 with the emergence of Stalinization - in its so-called 'Third Period' - ultimately brought the experiment in attempting to win over the masses to an end both in Russia and internationally when force and an unyielding demand for complete subordination to the Russian leader in domestic and foreign policy became all-pervasive. In studies of Gramsci and the Comintern, it seems to me at least that the shadow cast by Stalinism has fallen backward as well as forward, obscuring to some extent Gramsci's intellectual debt to the Third International.

This debt, though inadequately acknowledged, was not moreover an insignificant one if we turn to consider the enduring relevance of Gramsci's thought today. Gramsci's hegemony continues to incite interest among modernday political and social theorists - as well as political movements of both the Left and Right - precisely because 
many who read his work recognize that the democratic strategy at the heart of his theory is pregnant with empirical and normative insights for the study and practice of democratic politics. With a critical appropriation such insights can of course acquire a more general application to politics that need not be conducted within the strictly

revolutionary Marxist framework of analysis that Gramsci employed. ${ }^{71}$ This of course was the central preoccupation of the post-Marxist and pioneering radical democratic theory of Laclau and Mouffe whose work stands out as the most successful attempt to date to critically elaborate the democratic strategy at the heart of Gramsci's hegemony. Laclau and Mouffe, however, reconstructed Gramsci's hegemony within a poststructuralist and Lacanian paradigm that developed over the years in ways which are distant from Gramsci's original strategy - a development of course they never sought to conceal. Criticisms of their work have tended to focus on their abandoning of Marxist categories and the critique of capitalism. ${ }^{72}$ However, from this perspective it is the question of democratic agency which seems more problematic in their approach, since - in line with the wider ontological assumptions of the post structuralist tradition in their theorization of hegemony - they de-center, hollow out and destabilize subjectivity so the subject ends up precariously trapped between the Scylla and Charybdis of radical contingency and a structuration divested of all agency. ${ }^{73}$ This calls into question the emergence of any hegemonic subject sufficiently stable and unified to lead the rest of society. In Gramsci, by contrast, democratic leadership is centered on parties which are closely aligned with historically constituted social forces whose ideology has passed from 'the economiccorporate' to 'the universal' plane which is what allows them to exercise the crucial unifying and mediating role between political society and civil society at large. As noted above, managing the resulting tensions and sustaining a dynamic equilibrium in a bloc of this nature is part and parcel of hegemonic agency and democratic politics for Gramsci. ${ }^{74}$ Indeed, it is arguable that a return to the letter and context of Gramsci's thought and particularly his illuminating conceptions of balance and equilibrium - which this chapter has sought to explore to some extent - can still help us think through this problem of agency in relation to democratic strategy. For while Gramsci cannot of course provide us with ready-made answers to modern-day problems, it might be nonetheless that his profound understanding of the difficult yet surmountable challenge for political parties to balance the pursuit of core ideological goals with the demands of winning over a broad diversified mass in conditions of modern democracy - a charge which he first acquired through the Comintern's United Front - can still teach us something about how democratic politics is and should be conducted today.

\section{References}


${ }^{1}$ Perry Anderson, 'The Antinomies of Antonio Gramsci,' New Left Review 100 (1976-7), 5-78; Norberto Bobbio, 'Gramsci and the Conception of Civil Society,' in Gramsci and Marxist Theory, ed. Chantal Mouffe (London: Routledge and Kegan Paul, 1979), 21-47; Stuart Hall, 'Gramsci's Relevance for the Study of Race and Ethnicity,' Journal of Communication Inquiry 10 (1986), 5-27; Stuart Hall, 'Gramsci and Us,' Marxism Today, June 1987, 1-21; Ernesto Laclau and Chantal Mouffe, Hegemony and Socialist Strategy: Towards a Radical Democratic Politics (London: Verso, 1985). For a wider discussion of interpretations of Gramsci as a 'Western Marxist,' see, for example, Carl Boggs, The Two Revolutions: Gramsci and the Dilemmas of Western Marxism (Boston: South End Press, 1984) and Renate Holub, Antonio Gramsci: Beyond Marxism and Postmodernism (London and New York: Routledge, 2014).

${ }^{2}$ See Antonio Gramsci, Selections from Political Writings 1921-1926, ed. and trans. Quintin Hoare (London: Lawrence and Wishart, 1978), 426-40.

${ }^{3}$ Perry Anderson, Considerations on Western Marxism (London: Verso, 1979), 31; see also Giuseppe Vacca, 'Gramsci a Roma, Togliatti a Mosca,' in Gramsci a Roma, Togliatti a Mosca: Il carteggio del 1926, ed. Chiara Daniele (Turin: Einaudi, 1999), 1-149, especially at 3.

${ }^{4}$ Laclau and Mouffe, Hegemony and Socialist Strategy, 48-54.

5 Anderson, 'The Antinomies of Antonio Gramsci,' 12-15, 58-61.

6 See, though: Christine Buci-Glucksmann, Gramsci and the State, trans. David Fernbach (London: Lawrence and Wishart, 1980), ch. 9; Peter Thomas, The Gramscian Moment: Philosophy, Hegemony and Marxism (Leiden: Brill, 2009), ch. 6.

7 Anderson, 'The Antinomies of Antonio Gramsci,' 59; Laclau and Mouffe, Hegemony and Socialist Strategy, 61.

8 'Periodizing' Comintern strategies is a complex matter, since the boundaries between each are frequently difficult to demarcate chronologically. For a slightly different periodization than the above with greater focus on Bolshevization, see Kevin McDermot and Jeremy Agnew, The Comintern: A History of International Communism from Lenin to Stalin (Basingstoke: Palgrave Macmillan, 1996), xxi-xxii.

${ }^{9}$ Laclau and Mouffe, Hegemony and Socialist Strategy; see too Mouffe, On the Political (Abingdon and New York: Routledge, 2005).

${ }^{10}$ Comintern literature has grown significantly in the wake of the opening of the Russian State archives in 1989-90. See, for example, Norman LaPorte, Kevin Morgan and Matthew Worley, Bolshevism, Stalinism and the Comintern: Perspectives on Stalinization, 1917-53 (Basingstoke: Palgrave Macmillan, 2008); McDermot and Agnew, The Comintern; Kevin McDermot and John Morison, eds., Politics and Society under the Bolsheviks (Basingstoke: Palgrave Macmillan, 1999); Tim Rees and Andrew Thorpe, 
International Communism and the Communist International 1919-1943 (Manchester: Manchester University Press, 1998).

11 'Theses on the Conditions of Admission to the Communist International, 30 July 1920, presented by Trotsky,' in Theses, Resolutions and Manifestos of the First Four Congresses of the Third International, ed. Alan Adler and trans. Alix Holt and Barbara Holland (London: Pluto, 1983), 92-7.

${ }^{12}$ Fernando Claudin, The Communist Movement: From Comintern to Cominform (London: Penguin, 1975), $56-62$.

13 See George D. H. Cole, A History of Socialist Thought, Vol. IV, Part I: Communism and Social Democracy 1914-1931 (London: Macmillan, 1965), 287-342.

14 'Extracts from a Manifesto of the ECCI on the Conclusion of the Third Comintern Congress, 17 July 1921,' in The Communist International 1919-1943, Documents, Vol. I, 1919-1922, ed. Jane Degras (London: Oxford University Press, 1956), 282-3.

${ }^{15}$ See Vladimir I. Lenin, 'Left-Wing Communism: An Infantile Disorder,' in Vladimir I. Lenin, Collected Works, Vol. 31 (Moscow: Progress Publishers, 1965), 17-118. At the Third Congress Lenin railed against the defenders of the 'theory of the offensive' for their failure to develop a mass political strategy: 'We must ... win over to our side not only the majority of the working class, but also the majority of the working and exploited rural population. Have you prepared for this? Almost nowhere.' Vladimir I. Lenin, 'Speech in Defence of the Tactics of the Communist International,' in Collected Works, Vol. 32 (Moscow: Progress Publishers, 1965), 476-7.

16 John Ridell, 'Editorial Introduction,' in Toward the United Front: Proceedings of the Fourth Congress of the Communist International, 1922, ed. and trans. John Ridell (Leiden: Brill, 2012), 9-13.

${ }^{17}$ Quoted by Jane Degras in 'Extracts from an ECCI-RILU Manifesto on the United Front, 1 January 1922,' in The Communist International 1919-1943, Documents, Vol. I, 1919-1922, ed. Degras, 316.

${ }^{18}$ See 'On the Tactics of the Comintern' and 'Theses on the Workers' United Front,' in Toward the United Front, ed. Ridell, 1149-73.

${ }^{19}$ McDermot and Agnew, The Comintern, 31-3.

${ }^{20}$ See Mark McNally, 'Revisiting the Gramsci-Bukharin Relationship: Neglected Symmetries,' History of European Ideas 37 (2011), 365-75.

21 'On Tactics, 12 July 1921 (drafted by Russian Delegation in consultation with German Delegation; introduced by Radek),' in Theses, Resolutions and Manifestos of the First Four Congresses of the Third International, ed. Adler, 293-4.

22 'Session 14 - Saturday, 18 November 1922: Programme,' in Toward the United Front, ed. Ridell, 493. 
${ }^{23}$ See 'Extracts from the Theses on Tactics Adopted by the Fifth Comintern Congress, July 1924,' in The Communist International 1919-1943, Documents, Vol. II, 1923-1928, ed. Jane Degras (London: Frank Cass, 1971), 142-56. Reporting on the Comintern Programme at the Fifth Congress, Bukharin again insisted on the general application of NEP for the 'transition period' due to the perseverance of 'intermediate forces.' See Degras's introduction to 'Resolution of the Fifth Comintern Congress on the Programme of the Communist International, 8 July 1924,' in The Communist International 1919-1943, Documents, Vol. II, 1923-1928, ed. Degras, 161-3.

${ }^{24}$ Vladimir I. Lenin, Two Tactics of Social Democracy in the Democratic Revolution (London: Forgotten Books, 2012 [1905]).

25 'On the Tactics of the Comintern,' in Toward the United Front, ed. Ridell, 1158.

${ }^{26}$ As Kuusinen put it at the Fifth Enlarged Plenum of the ECCI (attended by Gramsci), we must 'consider the possibility that for a time the social democratic leaders will go along with us, but in our united front tactics we must always fight them, expose them, and defeat them.' Quoted by Jane Degras, 'The Fifth Enlarged Plenum of the ECCI,' in The Communist International 1919-1943, Documents, Vol. II, 19231928, ed. Degras, 185.

${ }^{27}$ Ridell, 'Editorial Introduction,' in Toward the United Front, ed. Ridell, 48.

28 'On the Tactics of the Comintern,' in Toward the United Front, ed. Ridell, 1158-60.

29 'Extracts from an ECCI Statement on the Events in Germany in October 1923, 19 January 1924,' in The Communist International 1919-1943, Documents, Vol. II, 1923-1928, ed. Degras, 68-78; see also Bernhard H. Bayerlein, 'The Abortive "German October," 1923,' in Politics and Society under the Bolsheviks, ed. Kevin McDermot and John Morison (Basingstoke: Macmillan, 1999), 251-62. For the theses on Bolshevization see 'Extracts from the Theses on the Bolshevization of Communist Parties Adopted at the Fifth ECCI Plenum, April 1925,' in The Communist International 1919-1943, Documents, Vol. II, 1923-1928, ed. Degras, 188-200.

${ }^{30}$ For the uneven and diverse application of Bolshevization and Stalinization see the essays in Laporte, Morgan and Worley, Bolshevism, Stalinism and the Comintern; especially Aldo Agosti, 'Stalinization and the Communist Party of Italy,' 146-66.

${ }^{31}$ Gramsci, Selections from Political Writings 1921-1926, 410.

${ }^{32}$ Gramsci, Selections from Political Writings 1921-1926, 409.

${ }^{33}$ Ibid. 355.

${ }^{34}$ Antonio Gramsci, Prison Notebooks, Vol. II, ed. and trans. Joseph A. Buttigieg (New York: Columbia University Press, 1996), N4, §38, 179-80. 
35 Gramsci's own resistance to the United Front prior to 1923-4 was also partly informed by a certain 'workerism.' He thus refused to embrace Comintern attempts to fuse the PCd'I with the PSI in 1922 because he claimed the PSI was 'fundamentally a peasant rather than a proletarian party!' Geoffrey Nowell Smith and Quintin Hoare, 'General Introduction,' in Antonio Gramsci, Selections from the Prison Notebooks, ed. Quintin Hoare and Geoffrey Nowell Smith (London: Lawrence and Wishart, 1971), xlix1 .

${ }^{36}$ See, for example, Bordiga's interventions at the PCd'I's Lyons Congress in 1926 where he argued that Lenin had taught that the Party should only mobilize mass support in the period immediately before the acquisition of power and that the history of the Bolshevik Revolution showed 'there are periods in which it is better to be few than many.' 'Minutes of the Political Commission Nominated by the Central Committee to Finalize the Lyons Congress Documents,' in Gramsci, Selections from Political Writings $1921-1926,313-39$, at 320-1.

37 Jules Humbert-Droz, 'Document 38: Letter from Humbert-Droz to Zinoviev, 5 April 1924.' Jules Humbert-Droz Archive, Istituto Gramsci Rome.

38 Jules Humbert-Droz, 'Document 58: Report to the Comintern Presidium by Jules Humbert-Droz, 29 September 1924,' Jules Humbert-Droz Archive, Istituto Gramsci Rome. Translated from the original French by the author. The documents in the Jules Humbert-Droz Archive in the Istituto Gramsci in Rome are comprised of 90 copies of letters and reports. The full Humbert-Droz Archive is housed at the International Institute of Social History, Amsterdam.

${ }^{39}$ Antonio Gramsci, Quaderni del carcere, Vol. III, ed. Valentino Gerratana (Turin: Einaudi, 1975), Q13, $\$ 29,1623-4$ - Gramsci, Selections from the Prison Notebooks, 203-4. English translation supplied where available and separated with dash.

${ }^{40}$ Gramsci, Quaderni, Vol. III, Q14, §18, 1676 - Gramsci, Selections from the Prison Notebooks, 204-5.

${ }^{41}$ Gramsci, Quaderni, Vol. III, Q14, §70, 1733-4 - Gramsci, Selections from the Prison Notebooks, 1523.

42 According to Gramsci, Bordiga for example had 'crystallized in him a permanent state of pessimism on the possibility for the proletariat and its party to remain immune from infiltrations of petit-bourgeois ideologies, without the application of extremely sectarian political tactics' which in the end rendered impossible 'the alliance between workers and peasants, and the hegemony of the proletariat in the anticapitalist revolutionary movement.' Gramsci, Selections from Political Writings 1921-1926, 299-300.

${ }^{43}$ Gramsci, Selections from Political Writings 1921-1926, 448.

44 Antonio Gramsci, Quaderni, Vol. III, Q13, §18, 1595-6 - Gramsci, Selections from the Prison Notebooks, 164. 
45 Antonio Gramsci, Quaderni, Vol. III, Q13, §18, 1591 - Gramsci, Selections from the Prison Notebooks, 161.

${ }^{46}$ Antonio Gramsci, Quaderni del carcere, Vol. II, ed. Valentino Gerratana (Turin: Einaudi, 1975), Q11, \$5, 1485-6 - Gramsci, Selections from the Prison Notebooks, 345-6.

${ }^{47}$ Gramsci, Quaderni, Vol. II, Q11, §13, 1400 - Gramsci, Selections from the Prison Notebooks, 423-4.

${ }^{48}$ Antonio Gramsci, Prison Notebooks, Vol. III, ed. and trans. Joseph A. Buttigieg (New York: Columbia University Press, 2007), N8, §21, 249.

${ }^{49}$ Gramsci, Selections from Political Writings 1921-1926, 253-4.

${ }^{50}$ Gramsci, Quaderni, Vol. III, Q19, §24, 2013 - Gramsci, Selections from the Prison Notebooks, 61.

${ }^{51}$ Gramsci, Quaderni, Vol. III, Q19, §24, 2017 - Gramsci, Selections from the Prison Notebooks, 66.

${ }^{52}$ Gramsci, Quaderni, Vol. II, Q6, §88, 763-4 - Gramsci, Selections from the Prison Notebooks, 263.

${ }^{53}$ Gramsci, Quaderni, Vol. II, Q7, §16, 865-6 - Gramsci, Selections from the Prison Notebooks, 237-8.

${ }^{54}$ Gramsci, Quaderni, Vol. II, Q7, §35, 886 - Gramsci, Selections from the Prison Notebooks, 357.

55 Gramsci, Quaderni, Vol. III, Q13, §7, 1567 - Gramsci, Selections from the Prison Notebooks, 243.

${ }^{56}$ Gramsci, Selections from Political Writings 1921-1926, 229-36.

${ }^{57}$ Gramsci, Prison Notebooks, Vol II, N8, §163, 327-8.

${ }^{58}$ Gramsci, Selections from Political Writings 1921-1926, 119.

${ }^{59}$ Ibid. $139-40$.

${ }^{60}$ Ibid. 401.

${ }^{61}$ See, for example, his references to the three constitutive elements of the modern political party in the Prison Notebooks including (1) the 'mass element'; (2) the 'principal cohesive element' [central leadership]; and (3) the 'intermediate element.' According to Gramsci 'the intermediate element' has a vital role since it 'articulates the first element with the second and maintains contact between them, not only physically but also morally and intellectually.' Gramsci, Quaderni, Vol. III, Q14, §70, 1733-4 Gramsci, Selections from the Prison Notebooks, 152-3.

${ }^{62}$ Gramsci, Selections from Political Writings 1921-1926, 401-2.

${ }^{63}$ Gramsci, Quaderni, Vol. III, Q12, §1, 1514-7 - Gramsci, Selections from the Prison Notebooks, 7-10.

${ }^{64}$ Gramsci, Quaderni, Vol. III, Q12, §1, 1522 - Gramsci, Selections from the Prison Notebooks, 15.

65 Antonio Gramsci, Quaderni del carcere, Vol. I, ed. Valentino Gerratana (Turin: Einaudi, 1975), Q1, §128, 116-7 - Antonio Gramsci, Further Selections from the Prison Notebooks, ed. and trans. Derek Boothman (London: Lawrence and Wishart, 1995), 10. 
${ }^{66}$ See Mark McNally, 'The Organization of Balance and Equilibrium in Gramsci's Hegemony,' History of Political Thought 29 (2008), 662-89.

${ }^{67}$ Gramsci, Quaderni, Vol. III, Q13, §17, 1584 - Gramsci, Selections from the Prison Notebooks, 182.

${ }^{68}$ Gramsci, Quaderni, Vol. I, Q5, §127, 662 - Gramsci, Selections from the Prison Notebooks, 253.

${ }^{69}$ Gramsci, Prison Notebooks, Vol. III, N8, §195, 346-7.

${ }^{70}$ Gramsci, Quaderni, Vol. II, Q10, §44, 1331 - Gramsci, Selections from the Prison Notebooks, 349.

${ }^{71}$ Valentino Gerratana - the editor of the critical edition of the Prison Notebooks and lifelong scholar of Gramsci - ultimately concluded as much arguing that the Prison Notebooks provide 'a general theory of hegemony.' However, it is highly debatable whether this was ever Gramsci's intention - hence my emphasis on a 'critical appropriation.' See Valentino Gerratana, Problemi di metodo (Rome: Riuniti, 1997); Thomas, The Gramscian Moment, 222.

${ }^{72}$ See, for example, Norman Geras, 'Post-Marxism?’ New Left Review 1/163 (1987), 40-82; Norman Geras, 'Ex-Marxism without Substance,' New Left Review 1/169 (1988), 34-61.

${ }^{73}$ For a discussion of their critics from these diametrically opposing positions, see David Howarth, Discourse (Buckingham: Open University Press, 2000), 121-5; for a wider defense of their poststructuralist account of structure and agency, see David Howarth, Poststructuralism and After: Structure, Subjectivity and Power (Basingstoke: Palgrave Macmillan, 2013).

${ }^{74}$ In Laclau this unity in the bloc is theorized as an 'empty space' characterized by the Lacanian category of 'lack' or 'an absent fullness' which allows one particular element to signify the unity of the whole in a 'chain of equivalence.' Ernesto Laclau, 'Why do Empty Signifiers matter to Politics?' in Ernesto Laclau, Emancipation(s) (London: Verso, 1996), 36-46. In this essay Laclau rejects the path of theorizing the unity of a bloc in terms of equilibrium 44) which is the path taken here and elsewhere. See McNally, 'The Organization of Balance and Equilibrium in Gramsci’s Hegemony.' 